\title{
Effect of nickel oxide substitution on bioactivity and mechanical properties of bioactive glass
}

\author{
VIKASH KUMAR VYAS*, A SAMPATH KUMAR, S P SINGH and RAM PYARE \\ Department of Ceramic Engineering, Indian Institute of Technology (Banaras Hindu University), Varanasi 221005, India
}

MS received 22 January 2016; accepted 24 February 2016

\begin{abstract}
A small amount of nickel oxide is doped in bioglass ${ }^{\circledR}$ system and it is replaced by silica. The use of $45 \mathrm{S5}$ glass composition is one such material able to bond strongly to bone within 42 days. The $45 S 5$ bioglass ${ }^{\circledR}$ system develops a hydroxyl carbonate apatite (HCA) layer, which is chemically and crystallographically similar to mineral phase of bone. But it has low fracture toughness and mechanical weakness due to an amorphous glass network and it is not compatible for load-bearing applications. In the present work, the effect of addition of nickel oxide that annualizes the improvement in its mechanical strength and bioactivity is studied. Bioactivity of base glass and doped glass samples were tested through their HCA abilities by immersing them in simulated body fluid (SBF) for different days. The formation of HCA was confirmed by FTIR spectroscopy and pH measurement. Densities and mechanical properties of samples were also increased considerably by increasing the concentration of nickel oxide.
\end{abstract}

Keywords. Bioactive glass; nickel oxide; FTIR spectrometry; X-ray diffraction; mechanical properties.

\section{Introduction}

The bioactive glasses have high level of bioactivity that shows physiological response at interface with soft and hard tissues $[1,2]$. The main advantage of this type of bioactive glasses are capable of bonding to bone and soft tissues very fast $[3,4]$, which is attributed to high level of surface reactivity [5-8]. Nowadays, various types of bioactive materials for bone repair have been developed with substitution of different dopants, namely $\mathrm{Co}^{2+}, \mathrm{Sr}^{2+}, \mathrm{Mg}^{2+}$, etc. [9-12]. The bioactive behaviour of these glasses showed the formation of hydroxyl carbonate apatite (HCA) layer on the implant that is chemically and crystallographically assist the same as mineral phase of bone. Although, it has low fracture toughness and mechanical weakness due to an amorphous glass network, it is not compatible for load bearing applications [13-15]. The bioactive glass holds the three-dimensional non-periodic glass structure during selective dissolution of cations (e.g., $\mathrm{Na}^{+}$) by suppressing the detachment of some other ions [16]. The presence of $\mathrm{SiO}_{2}$ also helps the precipitation or surface reconstruction of the loose silica-rich layer, and hence enhances the formation of hydroxyapatite layer [17-19]. Some researchers have tried to study the bioactivity and mechanical properties of bioactive glasses [20-23]. Sampath et al showed that the addition of $\mathrm{BaO}$ up to $1.6 \mathrm{~mol} \%$ in 45S5 bioactive glass enhances the bioactivity and improved the mechanical properties [24]. Vyas et al [25] in an earlier investigation had also shown that the addition of cobalt oxide up to $2.0 \mathrm{~mol} \%$ in $45 \mathrm{~S} 5$ bioglass has resulted in the increase in bioactivity of the glass in vitro. In a similar investigation,

*Author for correspondence (vkvyas.rs.cer11@itbhu.ac.in)
Azevedo et al [26] designed resorbable bioactive glasses to activate the hypoxia pathway by substituting $\mathrm{Co}^{2+}$ for $\mathrm{Ca}^{2+}$ and $\mathrm{Co}^{2+}$ for $\mathrm{Si}^{4+}$ in soda-lime-phosphosilicate system containing $0-4.0 \mathrm{~mol} \% \mathrm{CoO}$ by conventional melting process. Smith et al [27] studied the structural characterization of hypoxia-mimicking $45 \mathrm{~S} 5$ glass melted with $4.0 \mathrm{~mol} \%$ of $\mathrm{NiO}$ at $1450^{\circ} \mathrm{C}$ in platinum $-10 \%$ rhodium crucibles in air atmosphere. They found that nickel adopted a mixed structural role in $\mathrm{NiO}-\mathrm{SiO}_{2}-\mathrm{CaO}-\mathrm{Na}_{2} \mathrm{O}-\mathrm{P}_{2} \mathrm{O}_{5}$ bioactive glass occupying both network-forming tetrahedral and network-modifying five-fold symmetries. Structural correlation between 45S5 bioglass and nickel-doped bioactive glass revealed that isomorphic substitution of nickel in the silicate network in tetrahedral coordination or as modifier in higher coordination do not adversely affect the existing glass structure.

The present work aims to measure the bioactivity and mechanical properties of base glass and nickel oxide substitute bioactive glass. $\mathrm{Ni}^{2+}$ is being considered as a possible alternative to growth factors and genetic approaches in tissue engineering because of their easy processing and tunable release kinetics.

\section{Material and methods}

\subsection{Preparation of the bioactive glass composition}

The bioactive glass containing chemical composition $(46.14-\mathrm{X}) \mathrm{SiO}_{2}-24.40 \mathrm{Na}_{2} \mathrm{O}-26.91 \mathrm{CaO}-2.55 \mathrm{P}_{2} \mathrm{O}_{5}$ (where $X=0-1.65 \mathrm{~mol} \%$ of nickel oxide). In the present study, $\mathrm{CaO}, \mathrm{Na}_{2} \mathrm{O}$ and $\mathrm{P}_{2} \mathrm{O}_{5}$ concentrations were kept constant and 
Table 1. Composition of the bioactive glasses (mol\%).

\begin{tabular}{lccccc}
\hline Sample & $\mathrm{SiO}_{2}$ & $\mathrm{Na}_{2} \mathrm{O}$ & $\mathrm{CaO}$ & $\mathrm{P}_{2} \mathrm{O}_{5}$ & $\mathrm{NiO}$ \\
\hline 45S5 (base) & 46.14 & 24.40 & 26.91 & 2.55 & 0.00 \\
$\mathrm{NiO}-1$ & 45.64 & 24.41 & 26.94 & 2.60 & 0.41 \\
$\mathrm{NiO}-2$ & 45.20 & 24.44 & 26.96 & 2.61 & 0.82 \\
$\mathrm{NiO}-3$ & 44.71 & 24.46 & 26.98 & 2.61 & 1.23 \\
$\mathrm{NiO}-4$ & 44.25 & 24.49 & 27.01 & 2.61 & 1.65 \\
\hline
\end{tabular}

Table 2. Ion concentrations $\left(\mathrm{mM} / 1^{-1}\right)$ of $\mathrm{SBF}$ and human blood plasma.

\begin{tabular}{llllllllll}
\hline Ion & $\mathrm{Na}^{+}$ & $\mathrm{K}^{+}$ & $\mathrm{Mg}^{2+}$ & $\mathrm{Ca}^{2+}$ & $\mathrm{HCO}_{3}^{-}$ & $\mathrm{HPO}_{4}^{-}$ & $\mathrm{SO}_{4}^{2-}$ & $\mathrm{Cl}^{-}$ \\
\hline $\mathrm{SBF}$ & 142.0 & 5.0 & 1.5 & 2.5 & 4.2 & 1.0 & 0.5 & 147.8 \\
$\begin{array}{l}\text { Human } \\
\text { blood } \\
\text { plasma }\end{array}$ & 140.0 & 5.0 & 1.5 & 2.5 & 27.0 & 1.0 & 0.5 & 103.0 \\
\hline
\end{tabular}

$\mathrm{SiO}_{2}$ is partially replaced with nickel oxide. The compositions of prepared bioactive glasses are given in table 1 . The bioactive base glass and nickel oxide-doped glass are prepared by addition of nickel oxide $(0-1.65 \mathrm{~mol} \%)$ in place of $\mathrm{SiO}_{2}$ using normal melting and annealing technique. Materials used here include fine-grained quartz for silica. Lime and soda were introduced in the form of their respective anhydrous carbonates. $\mathrm{P}_{2} \mathrm{O}_{5}$ was added in the form of ammonium dihydrogen phosphate. The weighed batches were mixed thoroughly for $30 \mathrm{~min}$ and melted in platinum crucibles to get the desired bioactive glass. The melting was carried out in an electric furnace at $1400 \pm 10^{\circ} \mathrm{C}$ for $2 \mathrm{~h}$ in air as furnace atmosphere and homogenized melts were poured on preheated aluminum sheet. The prepared bioactive glass samples were directly transferred to a regulated muffle furnace at $450^{\circ} \mathrm{C}$ for annealing. After $1 \mathrm{~h}$ of annealing, the muffle furnace was cooled to room temperature with controlled rate of cooling at $10^{\circ} \mathrm{C} \mathrm{min}^{-1}$.

\subsection{Preparation of $S B F$}

Kokubo and his teams [28] developed simulated body fluid that has inorganic ion concentrations similar to those of human body fluid to reproduce in vitro formation of apatite on bioactive materials. The simulated body fluid (SBF) solution was prepared by dissolving reagent-grade $\mathrm{NaCl}, \mathrm{KCl}$, $\mathrm{NaHCO}_{3}, \mathrm{MgCl}_{2} \cdot 6 \mathrm{H}_{2} \mathrm{O}, \mathrm{CaCl}_{2}$ and $\mathrm{KH}_{2} \mathrm{PO}_{4}$ in doubledistilled water and it was buffered at $\mathrm{pH}=7.4$ with TRIS (trishydroxymethyl amino methane) and $1 \mathrm{~N} \mathrm{HCl}$ at $37^{\circ} \mathrm{C}$ as compared to the human blood plasma (WBC). The ion concentrations of SBF are given in table 2 [28].

\subsection{XRD measurements}

The bioactive glass samples were ground to $75 \mu \mathrm{m}$ and these fine powders were subjected to X-ray diffraction analysis
(XRD) using RIGAKU-Miniflex II diffractometer adopted $\mathrm{CuK} \alpha$ radiation $(\lambda=1.5405 \AA)$ with a tube voltage of $40 \mathrm{kV}$ and a current of $35 \mathrm{~mA}$ in a $2 \theta$ range between 20 and $80^{\circ}$. The step size and measuring speed were set to $0.02^{\circ}$ and $1^{\circ} \mathrm{min}^{-1}$, respectively, and were used in the present investigation. The JCPDS-International Centre for diffraction data cards were used as a reference.

\subsection{Structural analysis of bioactive glass}

The structure of bioactive glass samples were measured at room in the frequency range of $4000-400 \mathrm{~cm}^{-1}$ using a Fourier transform infrared spectrometer (FTIR) (Bruker Tensor 27 FTIR, USA). The fine bioactive glass powder samples were mixed with $\mathrm{KBr}$ in the ratio of 1:100 and the mixtures were subjected to a die at 10 bar pressure to produce clear standardized discs. The prepared discs were immediately subjected to IR spectrometer to measure the reflectance spectra to avoid moisture attack.

\subsection{In vitro study of bioactive glass}

To examine the formation of (calcium phosphate) apatite layer on the surface of the samples after immersion in SBF solution, the sample $(1 \mathrm{~g})$ was placed in $10 \mathrm{ml}$ of SBF solution in a small plastic container at $37^{\circ} \mathrm{C}$ with $\mathrm{pH} 7.40$ in an incubator at static condition for the time periods 1,3 and 7 days. After different days soaking, the samples were filtered, rinsed with doubly distilled water, and dried in an oven at $120^{\circ} \mathrm{C}$ for $2 \mathrm{~h}$ before analysis by FTIR.

\subsection{Measurements and mechanical behaviour of bioactive glass}

The melts were casted in rectangular shape moulds and the resultant bioactive glass samples were ground and polished for required dimension using grinding machine, then samples were subjected to three point bending test. The test was performed at room temperature using Instron Universal Testing Machine (AGS 10kND, Shimadzu) of cross-head speed of $0.5 \mathrm{~mm} \mathrm{~min}{ }^{-1}$ and full scale load of $2500 \mathrm{~kg}$. Flexural strength was determined according to ASTM standard: C158-02(2012). Using polished bioactive glass samples and the hardness testing machine, the size of the sample was $10 \times 10 \times 10 \mathrm{~mm}$ according to ASTM standard: C73098. The indentations have been made for loads ranging between 30 and $2000 \mathrm{mN}$, applied at a velocity of $1 \mathrm{~mm} \mathrm{~s}^{-1}$ and allowed to equilibrate for $15 \mathrm{~s}$ before measurement. The densities of casted bioactive glasses were measured by Archimedes principle with water as the immersion fluid. The measurements were performed at room temperature. Thin copper wire was used for immersing the samples into water. The density was determined by using ASTM: B96214. Compressive strength of the base glass and nickel oxidedoped bioactive glass samples having size of $1 \times 1 \times 1 \mathrm{~cm}^{-1}$ dimension according to ASTM D3171 were subjected to 
compression test. The test was performed using Instron Universal Testing Machine at room temperature (cross speed of $0.05 \mathrm{~cm} \mathrm{~min}^{-1}$ and full scale of $5000 \mathrm{kgf}$ ).

\section{7 pH measurement different days}

The $\mathrm{pH}$ of bioactive glass powder $(1 \mathrm{~g})$ was soaked in $10 \mathrm{ml}$ of $\mathrm{SBF}$ solution at $37^{\circ} \mathrm{C}$ for different time periods and the $\mathrm{pH}$ was measured using Universal Bio microprocessor $\mathrm{pH}$ meter. The instrument was calibrated each time with standard buffer solutions of $\mathrm{pH} 4.00$ and 7.00 at room temperature and $\mathrm{pH}$ values have been recorded during different time periods at a fixed time interval.

\section{Results and discussion}

\subsection{Structural investigation of base glass and nickel oxide-doped glasses}

The X-ray diffraction (XRD) patterns of base glass and nickel oxide-doped base glass are shown in figure 1 . The results indicate that the glasses have amorphous structure and there is no indentation for the presence of crystalline phases and it clearly shows that the nickel oxide completely dissolved in the glass matrix shown in figure 1. Vyas et al [25] in an earlier investigation had also shown that the addition

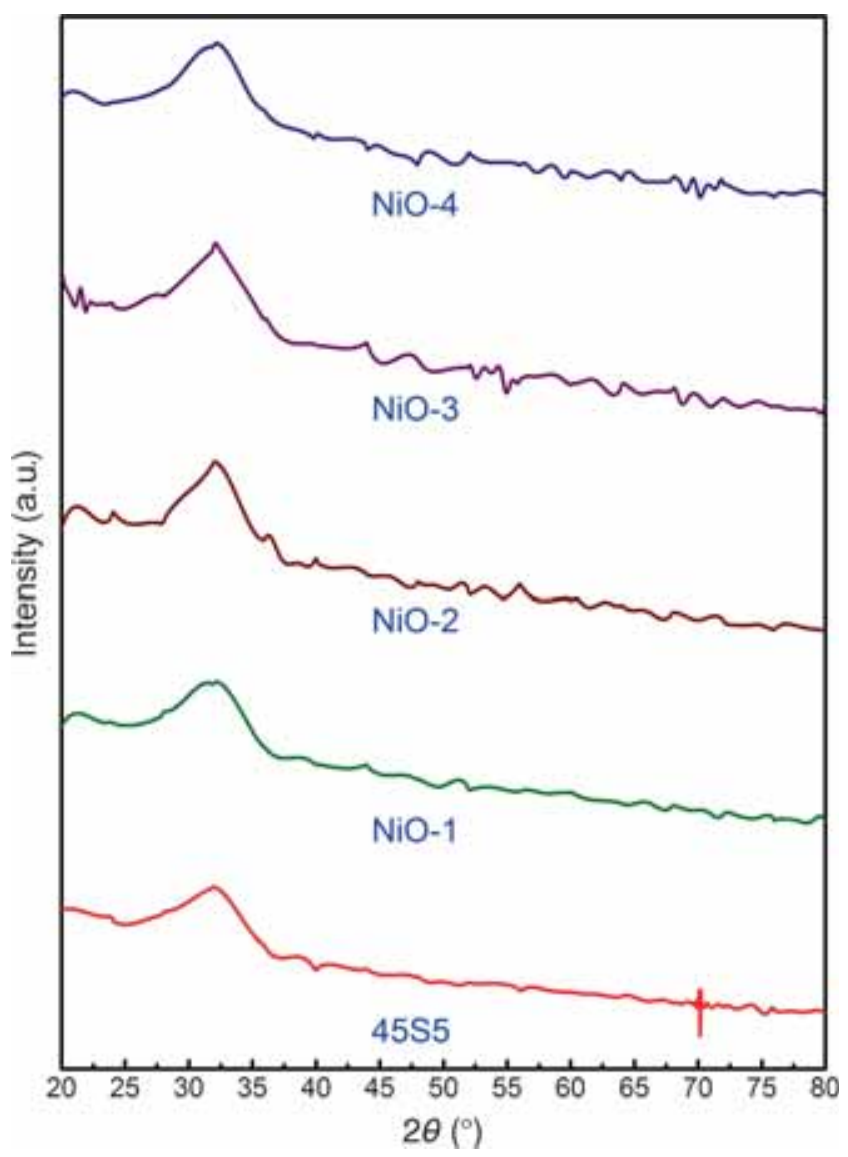

Figure 1. XRD of the bioactive glasses. of small amount of cobalt metal oxide up to $2.0 \mathrm{wt} \%$ in $45 \mathrm{~S} 5$ bioglass $\AA$ has resulted in amorphous structure. So, the small amount of metal oxides in glass matrix does not influence the glass structures. Figure 2 shows the FTIR reflection spectra of the base and nickel-oxide doped bioactive glass. All the bioactive glass samples were showing similar trend behaviour, FTIR reflection spectra bands of all the glasses confirm the main characteristic of silicate network and this may be due to the presence of $\mathrm{SiO}_{2}$ as a major element. Therefore, the bioactive glass (NiO-1) shows the peaks 495, 716, 1007, 1485 and $3768 \mathrm{~cm}^{-1}$. The resultant IR spectra at $495 \mathrm{~cm}^{-1}$ associated with a $\mathrm{Si}-\mathrm{O}-\mathrm{Si}$ symmetric bending mode, the band at $716 \mathrm{~cm}^{-1}$ corresponds to $\mathrm{Si}-\mathrm{O}-$ $\mathrm{Si}$ symmetric stretch of non-bridging oxygen atoms between tetrahedral. It was observed that the intensity of the band is recreated as the nickel oxide substitution in the base glass, therefore, the nickel oxide increases the non-bridging oxygen in the network. The major band at about $1007 \mathrm{~cm}^{-1}$ can be attributed to $\mathrm{Si}-\mathrm{O}-\mathrm{Si}$ stretching. The small band at $1485 \mathrm{~cm}^{-1}$ attributed to $\mathrm{C}-\mathrm{O}$ vibration mode. It was noticed that the intensity of the IR peak increased as the amount of nickel oxide increases which is due to the breaking of $\mathrm{Si}-\mathrm{O}-\mathrm{Si}$ network. The small broad band centred at about $3768 \mathrm{~cm}^{-1}$ can be assigned to hydroxyl group $(-\mathrm{OH})$, which may be due to the presence of adsorbed water molecules. This shows the infrared frequencies and related functional

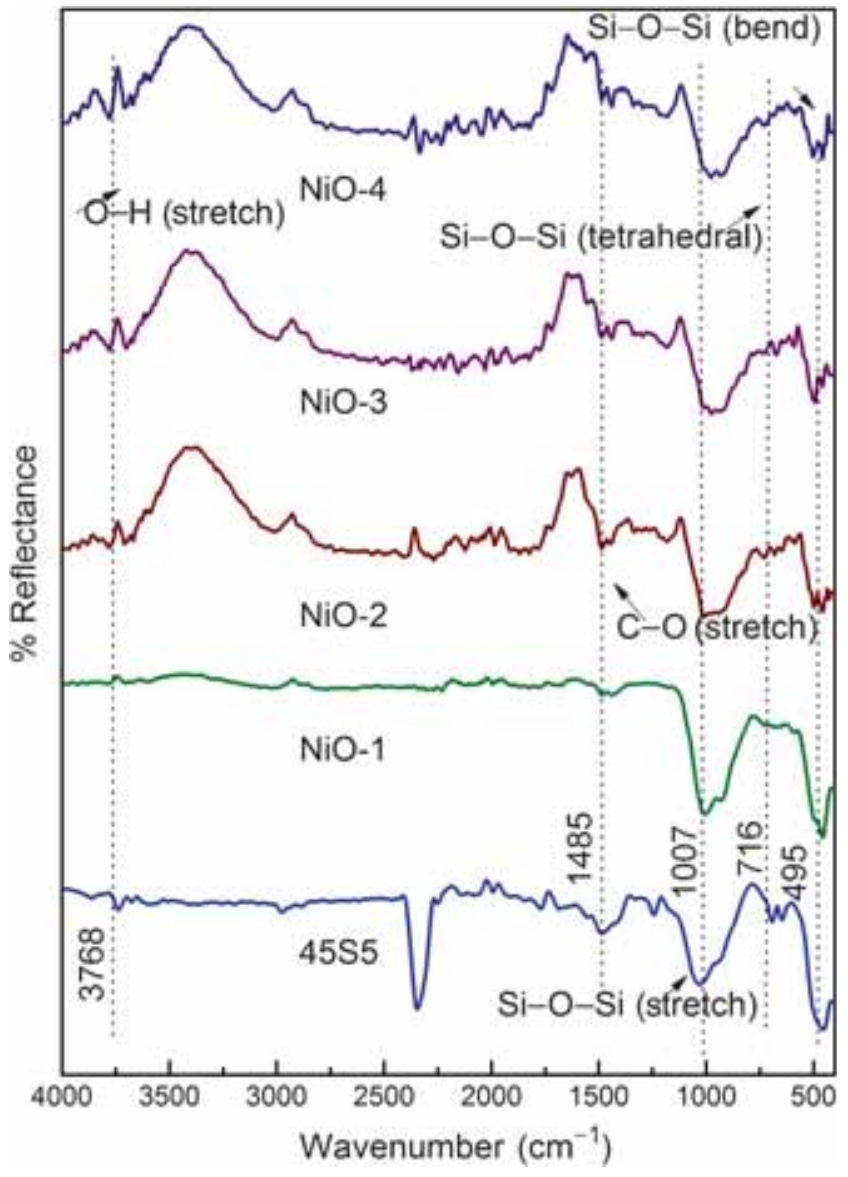

Figure 2. FTIR of the bioactive glasses. 


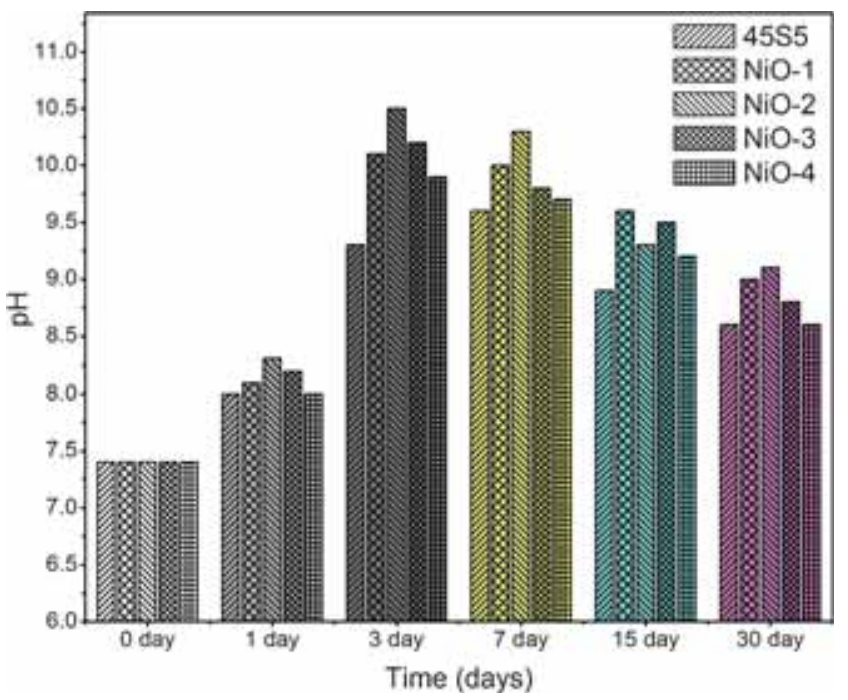

Figure 3. $\mathrm{pH}$ behaviour of the SBF after immersion of the bioactive glass samples.

structural groups in the bioactive glass [29]. The bioactive glasses substituted with nickel oxide are not showing noticeable changes in the IR spectra bands.

\subsection{Different day $\mathrm{pH}$ behaviour in $S B F$}

The difference in $\mathrm{pH}$ values of SBF after soaking the bioactive glasses for different time periods is shown in figure 3. It was observed that the $\mathrm{pH}$ of all samples show the similar trend in behaviour [30]. The highest $\mathrm{pH}$ values were recorded on 3rd day of immersion. It is interesting to note that the Ni-doped bioactive glasses demonstrated a higher $\mathrm{pH}$ values after immersing in SBF, which is due to the rapid release of cations from the surface compared with undoped sample. It was observed that this is due to the addition of nickel oxide in base bioactive glass (45S5). The sequence of reactions occurred in SBF after immersion of bioactive glasses for various time periods are in favour of formation of hydroxyl apatite like layer on the surface of the samples [31-33]. In general, higher is the degradation the higher would be the bioactive. Therefore, the nickel oxide-doped glasses expected to be highly bioactive. The sample numbers $\mathrm{NiO}-1$ and $\mathrm{NiO}-2$ showed highest $\mathrm{pH}$ among the others. The NiO- 1 and NiO-2 with 0.41 and 0.82 mol\% nickel oxide possessed higher $\mathrm{pH}$ and on further addition nickel 1.23 and $1.65 \mathrm{~mol} \%$ showed lesser $\mathrm{pH}$ values, which might have hindered the release of alkaline ions form the glass. It was reported that the transition metal ions in bioactive glasses often showed a largely controllable dissolution properties within physiological fluids and their exciting route for potential delivery systems within tissue regeneration scaffolds.

\subsection{In vitro study of bioactive glass by FTIR spectroscopy}

Figures 4-8 show the FTIR reflection spectra bands of the bioactive glass before and after their immersion in SBF for

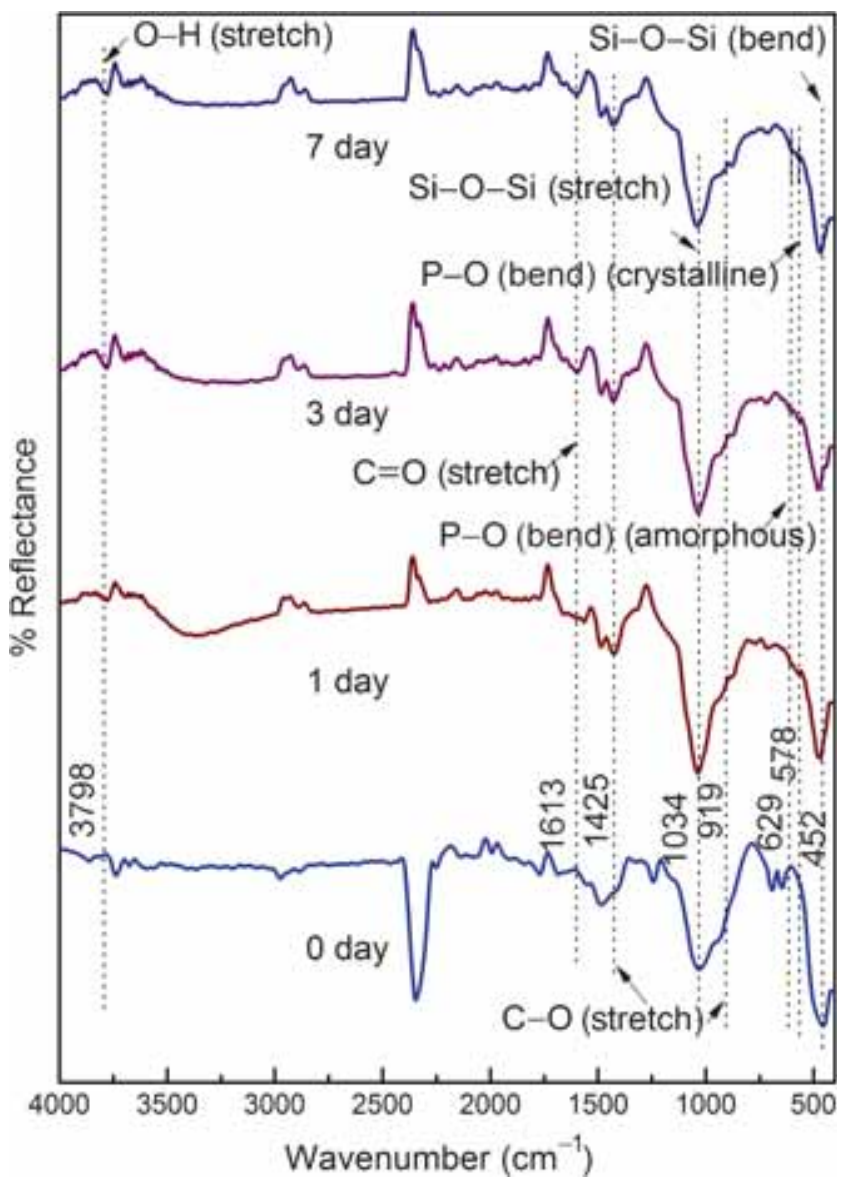

Figure 4. FTIR of the bioactive glass (45S5 bioglass) before and after immersion in SBF for different time periods.

different days of 0, 1, 3 and 7. Hench [34], Kim et al [35] and Rehman [36] confirmed that changes in the IR spectra bands after immersion in SBF for prolonged time period and the stages of apatite formation on the surface of the samples after immersion in SBF.

Figure 4 shows $45 \mathrm{~S} 5$ bioactive glass reflection spectra bands for $0,1,3$ and 7 days immersion in SBF. The new bands were found after 1 day immersion in SBF at 578 and $629 \mathrm{~cm}^{-1}$ correspond to $\mathrm{P}-\mathrm{O}$ bending (crystalline) and $\mathrm{P}-\mathrm{O}$ bending (amorphous), respectively, presence of $\mathrm{C}-\mathrm{O}$ stretching at $919 \mathrm{~cm}^{-1}$ band shows the crystalline nature, which indicates the formation of hydroxyl carbonate apatite (HCA) layer. The bands at about 1425 and $1613 \mathrm{~cm}^{-1}$ are associated with $\mathrm{C}-\mathrm{O}$ (Stretch) and $\mathrm{C}=\mathrm{O}$ (Stretch) stretching modes, respectively, and the band at about $3798 \mathrm{~cm}^{-1}$ can be assigned to (hydroxyl) O-H groups on the surface. The samples prolonged period in SBF shows the same behaviour with small decrease in the intensities of the bands, which resulted in the formation of HCA layer [37-39].

Figure 5 shows the IR spectra bands of NiO-1 sample for $0,1,3$ and 7 days treated with SBF. The new bands were appeared after 1 day immersion in SBF when compared to 0 day immersion at 554 and $603 \mathrm{~cm}^{-1}$ are corresponding to $\mathrm{P}-\mathrm{O}$ bending (crystalline) and $\mathrm{P}-\mathrm{O}$ bending (amorphous), respectively, presence of $\mathrm{C}-\mathrm{O}$ stretching at $881 \mathrm{~cm}^{-1}$ band 


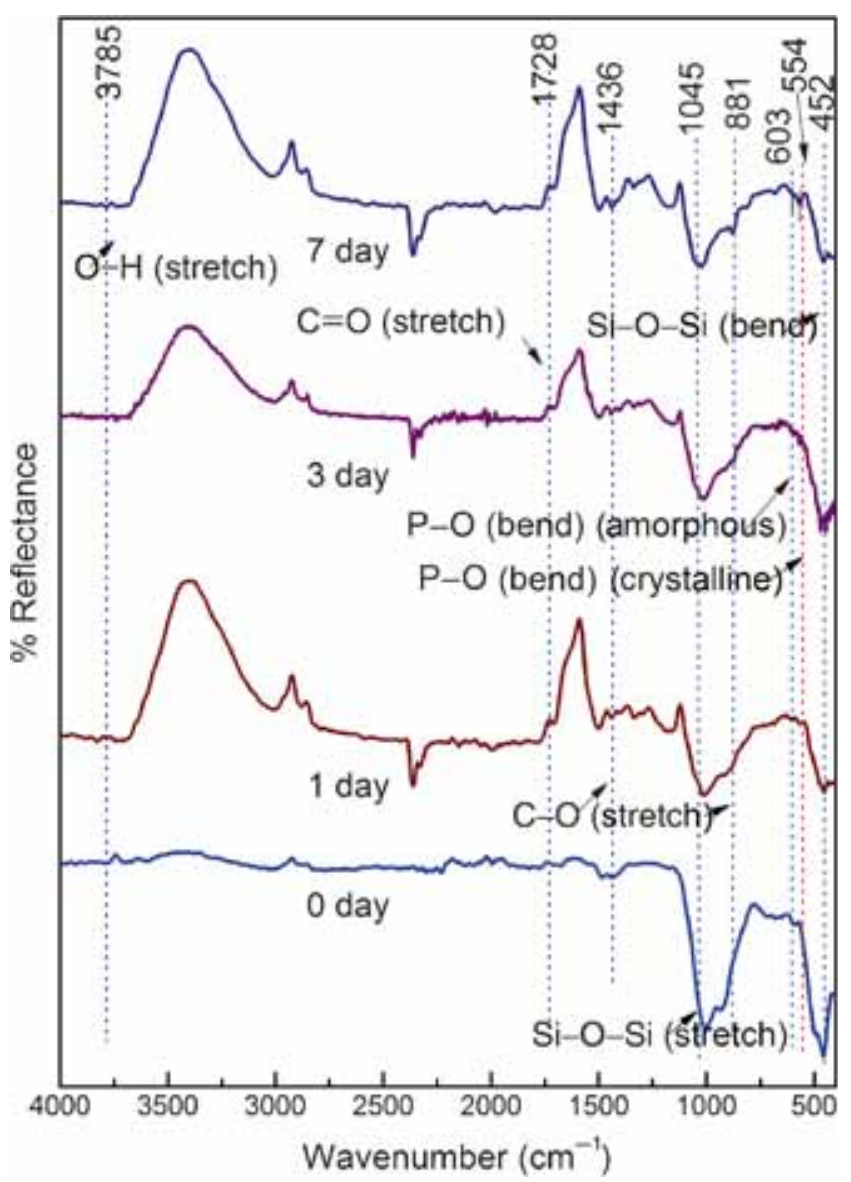

Figure 5. FTIR of the bioactive glass (NiO-1) before and after immersion in SBF for different time periods.

show the crystalline nature which indicates the formation of HCA layer. The bands at about 1436 and $1728 \mathrm{~cm}^{-1}$ are associated with $\mathrm{C}-\mathrm{O}$ (Stretch) and $\mathrm{C}=\mathrm{O}$ (Stretch) stretching modes, respectively, and the broad band at about $3785 \mathrm{~cm}^{-1}$ can be assigned to (hydroxyl) $\mathrm{O}-\mathrm{H}$ groups on the surface. The protracted period of the samples in SBF shows the same performance with small decrease in the intensities of the bands, which resulted in the formation of HCA layer.

Figure 6 shows the IR spectra bands of NiO-2 sample for $0,1,3$ and 7 days treated with SBF. The new bands were appeared after 1 day immersion in SBF when compared to 0 day immersion at 578 and $629 \mathrm{~cm}^{-1}$ are corresponding to $\mathrm{P}-\mathrm{O}$ bending (crystalline) and $\mathrm{P}-\mathrm{O}$ bending (amorphous), respectively, presence of $\mathrm{C}-\mathrm{O}$ stretching at $855 \mathrm{~cm}^{-1}$ band show the crystalline nature which indicates the formation of HCA layer. The bands at about 1436 and $1728 \mathrm{~cm}^{-1}$ are associated with $\mathrm{C}-\mathrm{O}$ (Stretch) and $\mathrm{C}=\mathrm{O}$ (Stretch) stretching modes, respectively, and the broad band at about $3710 \mathrm{~cm}^{-1}$ can be assigned to (hydroxyl) O-H groups on the surface. The protracted period of the samples in SBF shows the same performance with small decrease in the intensities of the bands, which resulted in the formation of HCA layer.

Figure 7 shows the IR spectra bands of NiO-3 sample for $0,1,3$ and 7 days treated with SBF. The new bands were

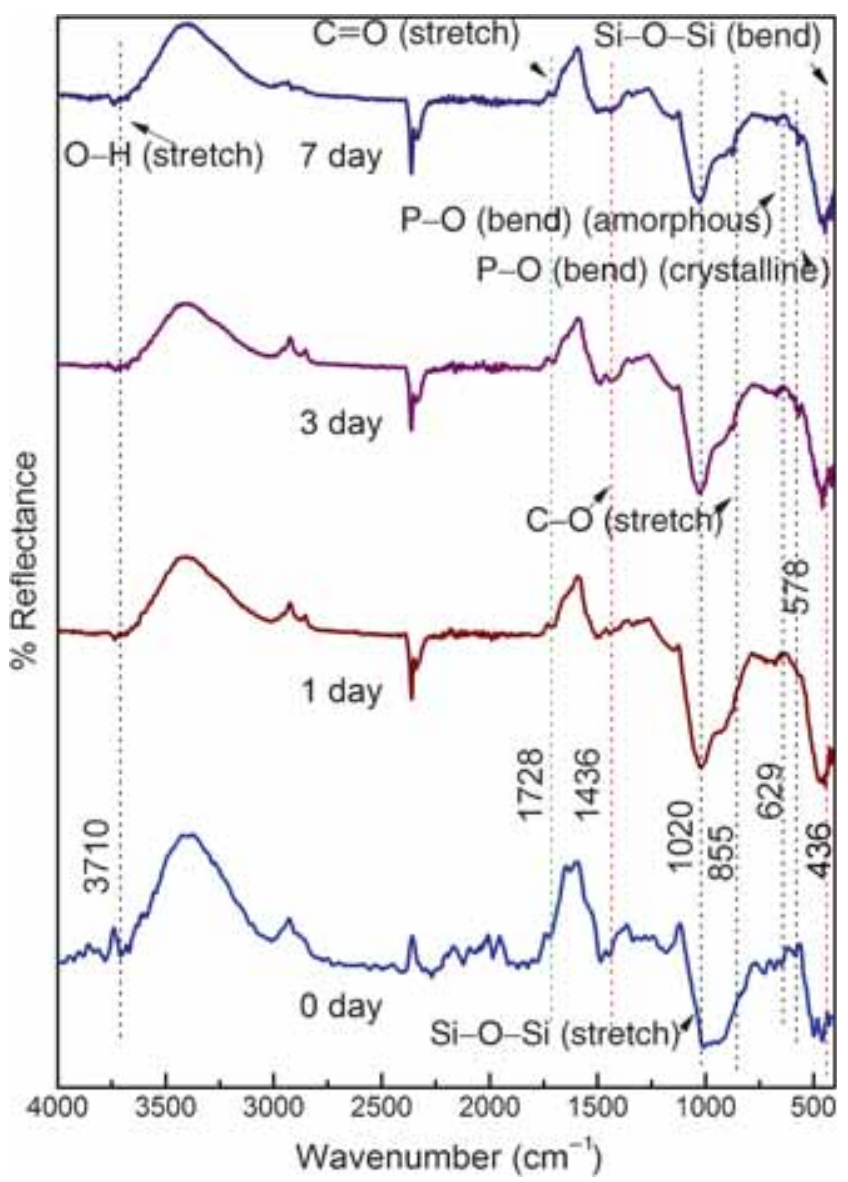

Figure 6. FTIR of the bioactive glass (NiO-2) before and after immersion in SBF for different time periods.

appeared after 1 day immersion in SBF when compared to 0 day immersion at 591 and $691 \mathrm{~cm}^{-1}$ are corresponding to $\mathrm{P}-\mathrm{O}$ bending (crystalline) and $\mathrm{P}-\mathrm{O}$ bending (amorphous), respectively, presence of $\mathrm{C}-\mathrm{O}$ stretching at $868 \mathrm{~cm}^{-1}$ band show the crystalline nature, indicating the formation of HCA layer. The bands at about 1425 and $1728 \mathrm{~cm}^{-1}$ are associated with $\mathrm{C}-\mathrm{O}$ (Stretch) and $\mathrm{C}=\mathrm{O}$ (Stretch) stretching modes and the broad band at about $3774 \mathrm{~cm}^{-1}$ can be assigned to (hydroxyl) O-H groups on the surface. The protracted period of the samples in SBF shows the same performance with small decrease in the intensities of the bands, which resulted in the formation of HCA layer.

Figure 8 shows the IR spectra bands of NiO-4 sample for $0,1,3$ and 7 days treated with SBF. The new bands were appeared after 1 day immersion in SBF when compared to 0 day immersion at 507 and $569 \mathrm{~cm}^{-1}$ are corresponding to $\mathrm{P}-\mathrm{O}$ bending (crystalline) and $\mathrm{P}-\mathrm{O}$ bending (amorphous), respectively, presence of $\mathrm{C}-\mathrm{O}$ stretching at $849 \mathrm{~cm}^{-1}$ band show the crystalline nature indicating the formation of HCA layer. The bands at about 1423 and $1774 \mathrm{~cm}^{-1}$ are associated with $\mathrm{C}-\mathrm{O}$ (Stretch) and $\mathrm{C}=\mathrm{O}$ (Stretch) stretching modes and the broad band at about $3779 \mathrm{~cm}^{-1}$ can be assigned to (hydroxyl) O-H groups on the surface. The protracted period of the samples in SBF shows the same performance with 


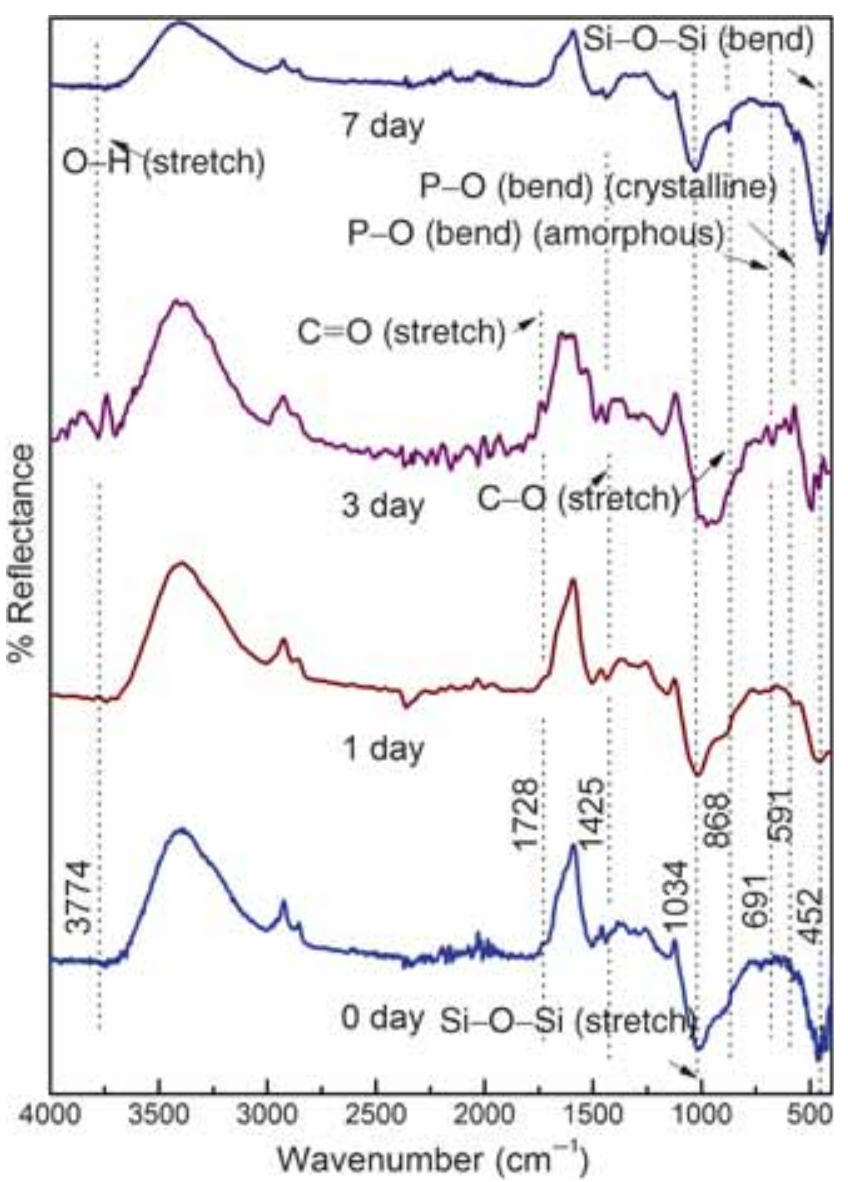

Figure 7. FTIR of the bioactive glass $(\mathrm{NiO}-3)$ before and after immersion in SBF for different time periods.

small decrease in the intensities of the bands, which resulted in the formation of HCA layer.

\subsection{Mechanical performance of base and nickel oxide-doped glass}

Figure 9 shows the density of nickel oxide-doped 45S5 bioactive glass. It is observed that the densities of the samples were increased with increasing nickel oxide content from 2.82 to $2.97 \mathrm{gm} \mathrm{cm}^{-3}$, which may be due to small amount replacement of $\mathrm{SiO}_{2}$ with $\mathrm{NiO}$, and is attributed to the replacement of a light element (density of $\mathrm{SiO}_{2}-2.64$ ) with a heavier one (NiO 6.67). Figure 10 shows the results of the flexural strength and microhardness for $45 \mathrm{~S} 5, \mathrm{NiO}-1$, NiO-2, NiO-3 and NiO-4 samples. The results show an increasing tendency in flexural strength and microhardness as the percentageof nickel oxide increase $(42.43,55.15,56.42$, 60.52 and $66.58 \mathrm{MPa}$; and 5.35, 5.48, 5.51, 5.77 and 5.99 $\mathrm{GPa}$, respectively). This increase may be due to the $\mathrm{Ni}^{2+}$ may act as network intermediate, thus for more compactness of glass structure [39]. This is also in agreement with density results shown in figure 9 that increase in density and decrease in the volume of the glass. This can be simply understood that bioactive glass doped with nickel oxide

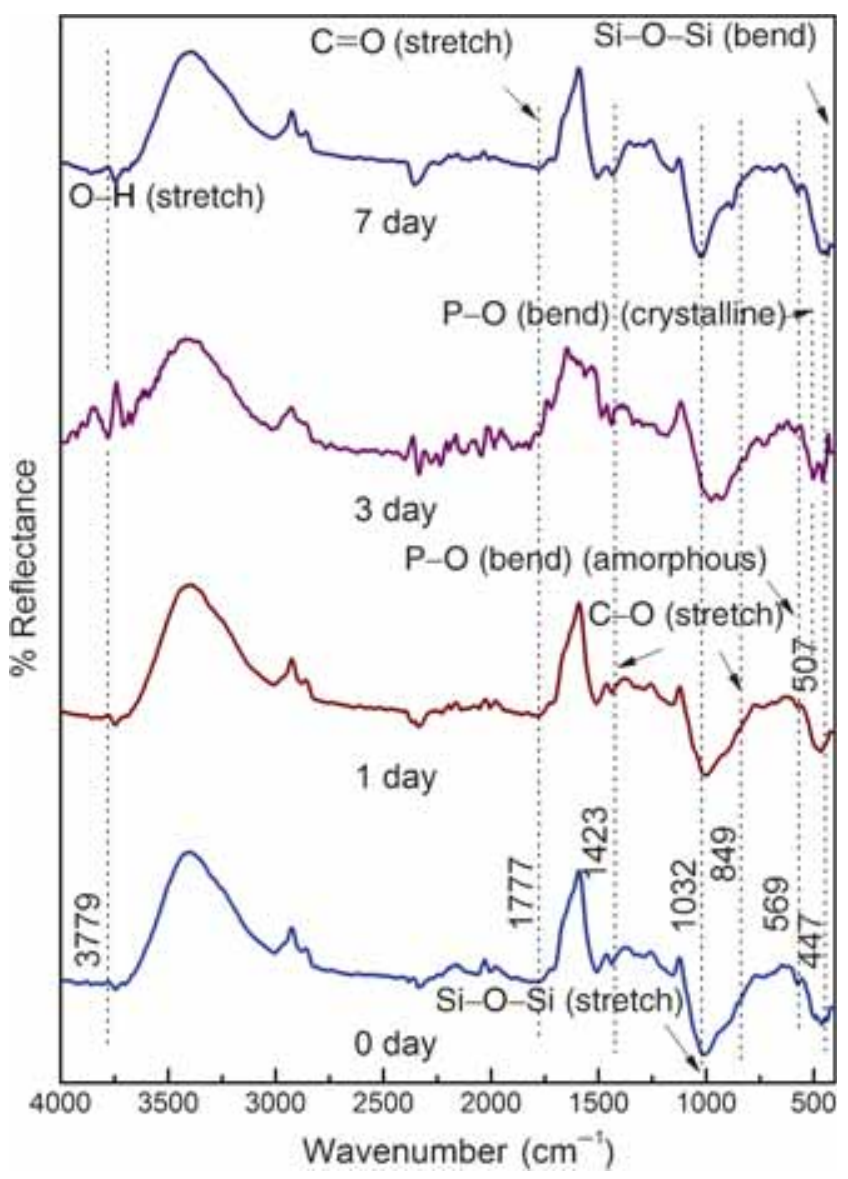

Figure 8. FTIR of the bioactive glass (NiO-4) before and after immersion in SBF for different time periods.

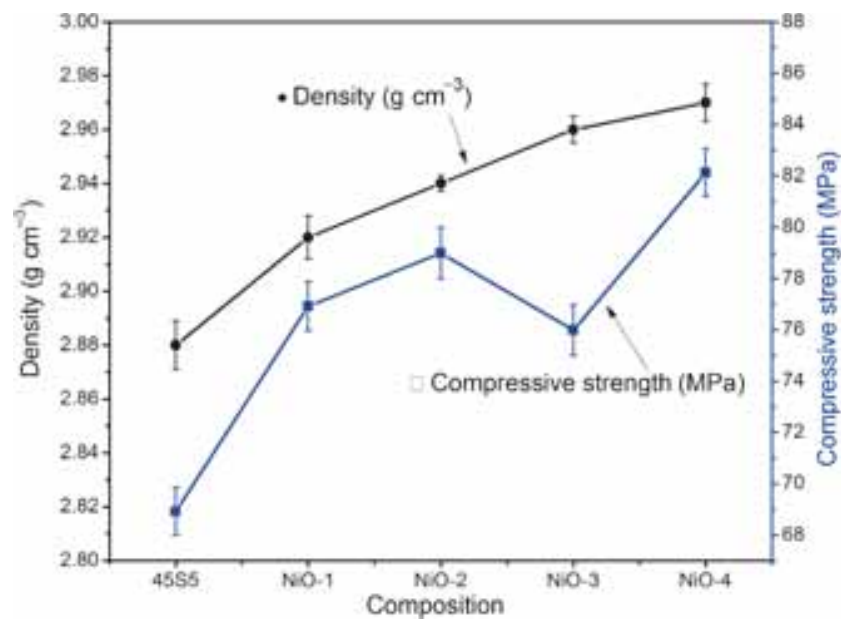

Figure 9. Density and compressive strength of the bioactive glasses.

demonstrates more flexural strength. Similar trend of results also found in the compressive strength (45S5, NiO-1, NiO-2, $\mathrm{NiO}-3$ and NiO-4 and 68.92, 76.92, 78.99, 75.98 and 82.13 $\mathrm{MPa}$, respectively) shown in figure 9 . The results obtained in this work is comparable with the previously reported studies of Srivastava et al $[39,40]$. 


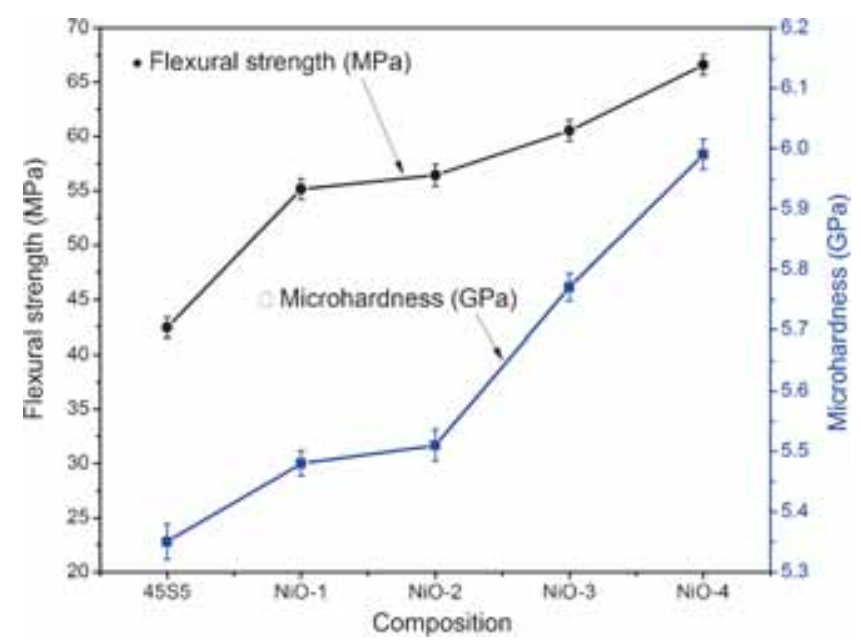

Figure 10. Flexural strength and microhardness of the bioactive glasses.

\section{Conclusions}

In the present investigation, a comparative investigation was made on physico-mechanical and bioactive properties of nickel oxide-doped 45S5 bioactive glasses. The following conclusions were drawn from this investigation. An increase in nickel oxide content in this series of glasses resulted in an increase in bioactivity. This is also supported by $\mathrm{pH}$. FTIR results showed the silicate network structure in prepared bioactive glass and increasing the nickel oxide content in 45S5 bioactive glass increase the density, flexural strength, compressive strength and microhardness.

\section{Acknowledgement}

We gratefully acknowledge the HOD, Department of Ceramic Engineering, Indian Institute of Technology (Banaras Hindu University), Varanasi, India and the honourable Director of Indian Institute of Technology (Banaras Hindu University), Varanasi, India, for providing necessary facilities for the present work. The author, Vikash Kumar Vyas is also very much grateful to the University Grants Commission, New Delhi, India (RGNF-SC-UTT-2012-13-25709) for providing the Rajiv Gandhi National Fellowship for the research work.

\section{References}

[1] Hench L L, Splinter R J, Allen W C and Greenlee T K 1971 J. Biomed. Mater. Res. 5117

[2] Hench L L and Anderson O 1993 An introduction to bioceramic (Singapore: World Scientific) p 41

[3] Zhong J P and Greenspan D C 1998 in Bioceramic 11 (ed.) R Z Legeros (Singapore: World Scientific) p. 415

[4] Neo M, Kotani S, Fujita Y, Nakamura T and Yamamuro T 1992 J. Biomed. Mater. Res. 261419

[5] Oonishi H, Hench L L, Wilson J, Sugihara E Tsuji, Matsuura M et al 2000 ibid $\mathbf{5 1} 37$
[6] Ducheyne P and Qiu Q 1999 Biomaterials 202287

[7] Hench L L 1991 J. Am. Ceram. Soc. 741487

[8] Leonor I B, Sousa R A, Cunha A M, Reis R L, Zhong Z P and Greenspan D 2002 J. Mater. Sci. Mater. Med. 13939

[9] Cabal B, Malpartida F, Torrecillas R, Hoppe A, Boccaccini A R and Moya J S 2011 Adv. Eng. Mater. 13 B462

[10] Padmanabhann S K, Gervaso F, Carrozzo M, Scalera F, Sannino A and Licciulli A 2013 Ceram. Int. 39619

[11] Vitale-Brovarone C, Nunzio S D, Bretcanu O and Vern E 2004 J. Mater. Sci. Mater. Med. 15209

[12] Martorana S, Fedele A, Mazzocchi M and Bellosi A 2009 Appl. Surf. Sci. 2556679

[13] Singh V K and Reddy B R 2012 Ceram. Int. 385333

[14] Simon V, Lucacel R C, Titorencu I and Jinga V 2011 Key Eng. Mater. 146385

[15] Soares P, Laurindo C A H, Torres R, Kuromoto N, Peitl O and Zanotto E 2012 Surf. Coat. Technol. 2064601

[16] Hench L L, Splinter R J, Allen W C and Greenlee T K 1971 J. Biomed. Mater. Res. Symp. (Part 1) 4117

[17] Hench L L 1991 J. Am. Ceram. Soc. 741487

[18] Hench L L and Paschall H A 1974 J. Biomed. Mater. Res. Symp. (Part 1) 549

[19] Hench L L 1997 Curr. Opin. Solid State Mater. Sci. 2604

[20] Castillo J, Yanes A C, Méndez-Ramos J, Velázquez J J and Rodríguez V D 2011 J. Sol-Gel Sci. Technol. 60170

[21] Assem E E 2005 J. Phys. D Appl. Phys. 38942

[22] Sanada T, Seto H, Morimoto Y, Yamamoto K, Wada N and Kojima K 2010 J. Sol-Gel Sci. Technol. 5682

[23] Ghasemzadeh M, Nemati A and Baghshahi S 2012 J. Eur. Ceram. Soc. 322989

[24] Sampath Kumar A, Tripathi H, Vyas V K, Jain S, Suman S K, Rana Pyare and Singh S P 2015 Mater. Sci. Eng. C 49549

[25] Vyas V K, Sampath Kumar A, Prasad S, Singh S P and Ram Pyare 2015 Bull. Mater. Sci. 38957

[26] Azevedo M M, Jell G, O'Donnell M D, Law R V, Hill R G and Stevens M M 2010 J. Mater. Chem. 208854

[27] Smith J M, Martin R A, Cuelloc G J and Newporta R J 2013 J. Mater. Chem. B 11296

[28] Kokubo T and Takadama H 2006 Biomaterials 272907

[29] Nayak J P, Kumar S and Bera J 2010 J. Non-Cryst. Solids 3561447

[30] Cerrutia M, Greenspanb D and Powers K 2005 Biomaterials 261665

[31] Hench L L 1998 J. Am. Ceram. Soc. 811705

[32] Mastelaro V R, Zanotto E D, Lequeux N and Cortes R 2000 J. Non-Cryst. Solids 262191

[33] Ducheyne P and Qiu Q 1999 Biomaterials 202287

[34] Hench L L 1998 J. Am. Ceram. Soc. 811705

[35] Kokubo T, Kim H-M and Kawashita M 2003 Biomaterials 242161

[36] Rehman I, Karsh M, Hench L L and Bonfield W 2000 J. Biomed. Mater. Res. 5097

[37] Mastelaro V R, Zanotto E D, Lequeux N and Cortes R 2000 J. Non-Cryst. Solids 262191

[38] Ducheyne P and Qiu Q 1999 Biomaterials 202287

[39] Srivastava A K, Pyare R and Singh S P 2012 Int. J. Sci. Eng. Res. 31

[40] Srivastava A K and Pyare R 2012 Int. J. Sci. Technol. Res. 128 